\title{
TEACHING ENVIRONMENTAL EDUCATION FOR SUSTAINABLE DEVELOPMENT: STRATEGIES AND CHALLENGES
}

\author{
Dinn Wahyudin ${ }^{1}$ and Ranbir Singh Malik ${ }^{2}$ \\ ${ }^{1}$ Universitas Pendidikan Indonesia, ${ }^{2}$ Edith Cowan Universityt (Australia)
}

\begin{abstract}
Building on a serious concern over excessive increase of production garbage waste from one year to another, this article argues that the garbage waste produced by cities around the globe has led to an environment crisis and the planet earth has faced desertification, drought, and degradation. Within this scenario, it is high time we brought this awareness by teaching environment literacy. To this end, the article discusses climate change as an inconvenient scenario, key challenges, tale of two dying rivers, education for sustainable development, and then approaches to environmental education.
\end{abstract}

\section{INTRODUCTION}

The new film, Blade Runner-2049 and Al Gore's Inconvenient Truth (2008) depict an earth in barely restrained crisis. Its exploding population has ruined all ecosystems and filled the world with trash. The planet Earth is in dire state. Loss of fresh water, species extinction, depletion of natural resources, increased habitat loss, increased global warming and climate change are the stark realities of our sick planet Earth. Exploding population, growing demand that human desires place upon the natural resources, globalization, and staggering strides in technology are the major forces which are changing the social, ecological, and demographic landscape of the earth. In A.D. 1 the world population was 200 million; in 18041 billion; in 2011 it shot up to 7 billion and figures for 2030 and 2050 are 9 billion and 10 billion, respectively. This galloping population is placing strenuous and unsustainable demand on the planet Earth. In cities like Beijing, New Delhi and Jakarta pollutants are scattered from millions of automobile exhaust pipes. Aquifers under cities in India are drying up as thousands of wells pump up ground water. Cities along the Holy Ganges River are dumping untreated water in the river making it a vast sewerage. Situation in Jakarta, Lagos and Bangkok and many other cities is equally hopeless. Industrialized farms are replacing small farms increasing the volume of pesticides and fertilizers, endangering the flora and fauna on river mouth. Greenhouse gas comes from the over exploitation of natural resources. Climate change is by far the biggest environmental crisis facing humanity. The planet Earth faces desertification, drought and degra- 
dation. Between 1995 and 2014, fifteen thousand extreme weather events have caused more than 525,000 deaths worldwide and losses of nearly US\$3trillion (Kreft et al., 2015). Climate change is directly responsible for the rise in global temperatures and increased frequency and scale of extreme weather and natural disasters. These in turn have a direct impact on global stocks, human health, security and economic growth. Natural resources have been over exploited. Not only a significant loss of biodiversity is occurring but also massive rise of carbon levels is leading to climate change and associated extreme weather. Toxic substances are increasingly found in air, water and flora and fauna. Even though the number of people living in extreme poverty has declined by over a billion (UNESCO 2015a) disparities between rich and poor continues to rise. The gulf between today's rich and the poor is a yawning gap that opened during the modern economic growth (Sachs, 2005, p. 28). Oxfam recently reported that the world's richest 62 people possess as much wealth as the poorest 3.6 billion (Hardoon et al., 2016). Too many people are trapped in poverty, and lack clean air and drinking water as well as adequate food and suffer from malnutrition. A Large number of people are forcibly displaced or on the run due to protracted conflicts such as in Syria and Yemen. Globally, everyday around 93\% children under the age of 5 years breathe air that is so polluted it puts their health at serious risk. Children die from acute lower respiratory infections caused by polluted air (WHO-2016). The Times of India (30 October, 2018) reported the data from Air Pollution and Child healthWHO-2016) stating that India tops under 5 deaths due to toxic air. Other countries are Nigeria, Pakistan and Congo in that order. In low and middle income countries $98 \%$ of children and in developed countries 52\% children under the age of 5 are exposed to air pollution of Particulate Matter. "Air pollution is stunting our children's brains, affecting their health in more ways than we suspected" (Maria Neira, WHO-2018). Beijing, New Delhi, Lagos, Jakarta and Karachi, in that order, are the cities with highest degree of air pollution.

The world now produces more than 9 billion tons of garbage a year which it incinerates, buries, exports and recycles. By 2025, according to a World Bank study (2014) the waste produced by cities around the globe will be enough to fill a line of rubbish trucks 3100 kilometers long. Africa, the fastest urbanizing continent is full of cities struggling to balance their extraordinary growth with sustainable waste management. Every year, improper garbage disposal contributes to devastating epidemics like ebola, typhoid, malaria, yellow fever and other fatal diseases. Discarded electronic waste, particularly in the developed countries, has become its own thing e-waste. It is out of this concern the concept of sustainable development (hereafter SD) was born.

Environment crisis is one of the most important contemporary crises. Lack of environmental awareness is the critical element that leads to environmental destruction. Teaching about the environmental education (hereafter EE) is the best tool for facing the future envi- 
ronment challenges. Schools are the first and best platform for targeted training of environmental concepts. This paper draws attention to the need for EE, Education for Sustainable Development (ESD) and the possible strategies to adopt environmental curriculum and the challenges we face.

\section{Chimate change: \\ INCONVENIENT SCENARIOS}

Humans are changing the climate much faster than has ever happened naturally, and so natural processes of adaptation and evolution cannot keep up and that is why we are seeing these incredible impacts (Wachefeld, Strait Times, October25, 2018). Air pollution, water pollution, unexpected climate change, garbage and pollution of the natural environment are some of the challenges faced by the world today. Global emission of carbon dioxide has dramatically increased since the middle of the 20th century, as the energy consumption increased at a phenomenal level. In the 1990 s, $80 \%$ of the world's energy supply came from fossil fuels. Fuel combustion accounts for $85 \%$ of air pollution. Temperatures rise because of the increasing acidity arising from growing amounts of carbon dioxide coming from burning fuels. The multiple threats of environmental degradation and climate change have assumed an unprecedented urgency to which we are all obliged to respond. With the planet heating and growing numbers of people putting increasing pressure on water and food supplies and on life-sustaining ecosystems, in $\mathrm{Al}$ Gore's (2008) words the inconvenient truth is humans are recklessly using the resources with little consideration of the welfare of the generations to come. The conversion of natural lands to croplands (e.g. Borneo and Amazon), urbanization (e.g. cities in India, Indonesia and other cities in Asia and Africa), and reservoirs are the most visible and pervasive form of human impact on the environment.

During the past three decades different parts of the world have been subject to the catastrophic accidents, some triggered by natural forces and others created by humans, but all have impacted on the environment. There is plenty of anecdotal evidence to suggest that our climate is beginning to act strangely. A staggering number of 35000 people were killed in 2003 when massive heat waves spilled across Europe; hurricane Katrina drowned New Orleans, in 2005; four-fifth of Kerala (India) was drowned by unprecedented rainfall in four days (August, 2018); and receding glaciers in Iceland, the Himalayas and Antarctica. Human imprints on the rivers, beaches, mountains and forests have dealt and continuing massive blow on fragile ecosystems to an unsustainable and unacceptable level. Human-made disasters coupled with natural forces serve wakeup calls but we ignore at our own peril. On December 2, 1984 an accident at the Union Carbide pesticide plant in Bhopal-India, released 30 tons of highly toxic gas, killing 15000 people and exposing 600,000 to the deadly gas. Chernobyl nuclear disaster (25-26 April, 1986) in Ukraine lead to a major release of nuclear radioactive material into the atmo- 
sphere. This nuclear fallout had a major impact on both agricultural and natural ecosystems in Ukraine, Russia and the neighboring East European countries. Cyclone Tracy on the Christmas Day in 1974 destroyed $80 \%$ of the city of Darwin. Recent typhoon in Hong Kong (September, 2018) wrought havoc with massive damage to the property. In 1988 Bangladesh cyclone killed 6240 people and wiped out $70 \%$ of all harvestable crops. On December 26, 2004 an earthquake of 9.1 magnitude caused immense tsunami up to the height of 30 meters. It killed 250,000 people in Banda Aceh (Indonesia), Phuket (Thailand) alone and effect of tsunami was felt up to east coast of Africa. Severe forest fires in California, Greece, Spain, Australia and Sumatra are regular features due to the rising temperatures. Receding glaciers in Antarctica, Alaska, Iceland and the Himalayas are the result of rising temperatures on the planet Earth. Volcanic eruptions in Lombok (April, 2018) and Palu (September 2018) monsoonal floods and human concentration in cyclonic prone flood plains of Bangladesh serve the reminder that in over populated places humans take risk to feed themselves. The Pacific Island Region will experience some of the most profound negative effects of climate change.

\section{Key Challenges}

It is now widely apparent and acknowledged that humanity's current use of biosphere is not sustainable. Climate change is by far the biggest environmen- tal crisis facing humanity. It is directly responsible for the rise in global temperatures and increased frequency and scale of extreme weather and natural disasters. These in turn have direct impact on global food stocks, human health, security and economic growth. Although considerable progress has been made to strengthen environmental education global community needs to create much more awareness and take action for the common good of all people while not depriving future generations to enjoy their existence on planet Earth.

International efforts to address the threat of climate change commenced in the late 1980s, culminating in the adoption of UN Framework Convention on climate change which was adopted at the Earth Summit in 1992. The Kyoto Protocol (1997) was adopted at the Third Conference of the parties to the earlier framework convention. The developed countries agreed to the differentiated mandatory targets. They made a commitment to reduce their Green House Gas emissions by $8 \%$ from the 1990 levels by the period 2008-2012. Rapidly developing countries (e.g. China, India and Indonesia) did not agree to any specific figure. They argue that their development and alleviation of poverty depends on the cheapest option of energy. They also argue that compared to the developed world their share of energy consumption is very low. Some unconfirmed calculations argue that the developed countries consume $80 \%$ of world's energy and if the living standard of the developing countries rises 
to the level of middle in the developed countries we need another planet with the size of the Earth and with similar amount of resources. Main argument of the developing countries is that per capita basis the consumption of energy in the developed world is far more compared to the developing countries.

Reversing climate change requires an integrated approach to learning. In a number of the countries at university level many initiatives are being undertaken to engage students in environmental issues and conducting research to suggest the ways to solve problems related to environment. Formal education plays particularly strong role in mitigating climate change and responding to its impact. Singapore has launched special six part series (October, 2018) on Climate Change to create awareness about the problem of global warming. The series focuses on saving the rainforests, Great Barrier Reef, Water Crisis in South Africa's Cape Town. In Australia, European Union, Japan and in many other countries plastic bags have been banned. In big cities of India buses use CNG. There is a big push towards the shift to harness the sources of renewable energy. Sadly, damage rendered to the environment is colossal and still political and economic considerations impede any progress towards cleaning the environment. It is against this gloomy background there is an urgent need to launch global campaign to incorporate environmental education in school curricula to educate the society for sustainable development.
In fact, Environmental Science is becoming a major course for students in universities. Today Despite the success of the programs, significant challenges remain in transitioning the wholeschool approach to Education for Sustainable Development (ESD) from the pilot stage to a wide spread systematic implementation in the formal education sector. Time and resource constraints are identified by teachers and school administrators as common barriers to ESD implementation. Adopting a whole-school approach to teaching and learning is viewed by many as simply impractical given current constraints on teachers' time within already crowded curricula (Henderson and Tilbury, 2004). Many teachers and administrators conceptualize as an add-on rather than a holistic change in teaching in teaching and learning practices. It has to be embedded into our daily educational practices. "We will consume what we love. We will love only what we understand. We will understand what we are taught" (Saylan and Blumstein, 2013).

Studies show gaps in appropriate pedagogy and curriculum development in teacher training, the absence of a positive vision and a general lack of conviction that individual teacher efforts will really make a difference. Teachers also require greater capacity to undertake the immense and challenging task of implementing a whole-school approach to ESD. Enhanced pre-service and in-service teacher training is urgently required for educators to be able to act as effective facilitators in the ESD 
process. A whole-school approach to ESD presents a significant opportunity for formal education sector. Implemented appropriately, schools can raise the quality of environmental education and build more sustainable societies. Commitment to change is required from all stakeholders, grass root activists educators and policy makers.

\section{Tale of Two Dying RIVERS: CITARUM AND THE GANGES}

India (1.35 billion) and Indonesia (260 million) are the second and fourth most populated countries in the world. Both countries are emerging economic powerhouses. National capitals of both countries are among the five most air polluted cities. In both countries due to the improving economic situation demand for automobiles and houses has shot up dramatically. The most prestigious rivers (Citarum-Indonesia) and (The Ganges-India) are rated as the most polluted rivers. Indonesia has serious environmental problems with filthy and clogged rivers, unbreathable air in big cities and garbage on streets. It is also the world's third largest emitter of carbon dioxide. Huge problem of deforestation (clearing land for palm oil and rubber plantation), frequent forest fires and burning of paddy stubbles and rapid loss of mangroves add to the problem due to exploding population and increased demand on natural resources.

Although Indonesia holds six percent of the world's fresh water resourc- es, the quality of its public piped water is contaminated with E. Coli, fecal coliforms. About eighty percent of Indonesia's population lacks access to piped water and relies on river water for drinking, washing and bathing. Water of most Indonesian rivers does not meet safe drinking water requirements. Due to weak awareness, weak compliance and weak law enforcement domestic and industrial waste is continuously being discharged in to rivers. Rivers near the mining sites contain high level of mercury. For safe drinking water people (mostly in urban areas) rely on bottled water. Empty bottles and plastics thrown in rivers and sewer block the flow of water especially during monsoonal period and lead to contamination. Skin disease diarrhea, and typhoid are very common diseases.

Citarum River is a glaring example of a polluted river. This river is vital for 25 million people who daily depend on it for agriculture, water for the Jatiluhur Reservoir which is Indonesia's biggest reservoir. This most strategic reservoir supplies clean water for Bandung and Jakarta and irrigates 400,000 hectares of paddy fields Citarum River supplies water to textile factories. Sadly, everyday no less than 20,000 tons of waste and 340,000 tons of waste from 2000 textiles factories are disposed into the river (Tarahita and Rakhmat, 2018). Amount of waste is so much that at places water cannot be seen and it is colored due to the excessive amount of toxic chemicals. It is completely chocked with plastic and empty plastic bottles. Organic 
waste pollution increases at an alarming rate. In February 2018, after visiting Citarum River President Jokowi Widodo declared a seven year Citarum Cleaning Program and to make water drinkable by 2025 . This project to clean the river is supported by International Monetary Fund and Asian Development Bank. Indonesian army has been given the task to clean this most polluted 300 kilometer long river. Government has made legal commitment (Law No.32/2009) on Environment Protection and Management but Indonesia did not do well in its 'Report Card' for Millennium Development Goal promoting environment sustainability.

Two thousand five hundred kilometer long the Ganges is India's most iconic and holiest river. It is so polluted that it is also called world's biggest sewerage. The Ganges is the primary source of water for 400 million people who rely on it for domestic and industrial use. Located on the banks of this river are 120 towns and cities which dump 4.8 billion liters of untreated sewerage water into it. An additional 500 million liters of industrial effluent gush into the Ganges daily from 760 industrial units.

June 5, 2018 was celebrated as World Environment Day with a theme Beat Plastic pollution. India was chosen as the host nation. Government of India formed 19 teams to clean 48 polluted water bodies, beaches, lakes and waterfronts across India. Environment Minister of India requested all schools across the country to go plastic free. Cleaning Ganges was particularly tar- geted. Schools and colleges which made big efforts were presented Green School Certificates. In 2018, Prime Minister of India Narendar Modi was awarded 'Champions of Earth Award' for his commitment to environment including to eliminate single-use plastics by 2020 . India built nine million toilets during the past four years and has started the campaign Swachch Bharat Movement (clean India).

River Praya Chaya of Thailand, Mekong and Irrawady and Rivers of China are not any better and they deserve equal attention for cleanliness. In most of the South and Southeast Asian countries potentials for renewable and alternative sources of energy are tremendous. For example, India and Australia have huge potentials for solar and wind energy, and Indonesia has huge potentials for thermal energy (due its location on the Ring of Fire). Educational institutions should take into account in making the citizens aware of the huge benefits of such alternatives for cleaner environment.

\section{INDONESIAN IMPRINTS ON ECOSYSTEM}

In many countries where environmental education is weak and pressure of population growth is high there is an urgent need to educate children and citizens about the adverse effects of our reckless use of resources. Indonesia is the fourth most populous nation, rising economic power, largest Muslim population and home of vast and varied natural resources. There is an imbalance be- 
tween population growth and attacks on biodiversity. Outbreaks of forest fires and burning of stubbles on paddy fields emit large amounts of carbon dioxide to atmosphere. Rising middle class puts more demand for automobiles, timber and water resources. Traffic congestion at the time of Eid celebration is a nightmare on roads, especially in big cities like Jakarta and Bandung. Indonesia has one of the worst mercury problems. In Indonesia, child labor is common in the gold fields, with boys as young as eight digging the ore and as young as 12 burning the mercury-gold amalgam (Bose O'Rielly 2017 a children's health expert).

Vast rainforests of the island of Borneo are inhabited by head-hunting tribes of Dayaks and home of exotic animals and plants and source of scarce and valuable products. Until the latter half of the 20th century, forests covered most of the island of Kalimantan and small trading posts at the river mouths. In the late 1960s, construction booms in Japan, Europe and North America and the availability of chain saws and tracked vehicles led the beginning of industrial-scale logging for international markets. During this period also Indonesian government's policy to resettle people from the densely settled island of Java in the frontier areas of the outer islands of Indonesia. In 1970s and 1980s major investments were initiated to open up the remote forests in Kalimantan. New roads were constructed for logging and to provide access to areas of planned agricultural settlement (transmigration). Central institutions established foot- holds throughout the region. Significant commercial development took place. It led to increased concern locally and internationally about the potentially harmful social and environmental impacts of transmigration and logging. Indonesian government launched some programs to improve the sustainability of transmigration and forestry. In the 1980s and 1990 s shifting agriculture was seen as the main threat to environment in $\mathrm{Ka}$ limantan. The resultant fallows were often invaded by the fire-dependent grass and the forests were often progressively transformed into fire-climax grasslands. The harvesting of non-timber forest products was recognized as a profitable and sustainable use of the forests. The negative consequences of the investments in both trans-migrant agriculture and industrial forestry became issues for international companies. Outside investors were both degrading the environment for short-term profit and disrupting the economies of the local inhabitants. It led to the pathways for better integration of a diversity of sustainable agriculture and forestry practices to maintain environmental services and biodiversity. In 1993, the Centre for International Research (CIFOR) was established in Indonesia to research more environmentally and socially sustainable management of forest lands.

\section{EDUCATION FOR Sustainable DeVelopment (ESD)}

Education for sustainable development is an integral element of quality ed- 
ucation and a key enabler for sustainable development. It empowers the people to change the way they think and work towards sustainable future. The main focus of ESD is "to transform society by reorienting education and help people develop knowledge, skills, values and behaviors needed for sustainable development. It includes issues such as climate change and biodiversity into teaching and learning" (http://en.unesco/org/ themes/education-sustainable-development-esd). ESD is an interdisciplinary learning methodology covering the integrated social, economic and environmental aspects of formal and informal curriculum. United Nations had declared the decade (2005-14) the Decade of Education for Sustainable Development with a goal to provide opportunity for refining and promoting the vision of transition to sustainable development through all forms of education, public awareness and training.

\section{SUSTAINABLE DEVELOPMENT (SD)}

Sustainable development is an organizing principle for global development that supports the wellbeing of both people and the planet (UNESCO, 2016). SD advanced in the 1960s and 1970s became a major public concern in the 1980s. At the 1986 Conference on Conservation and development in Ottawa, SD was defined as (a) integration of conservation and development; (b) satisfaction of basic human needs; (c) achievement of equity and social justice; (d) provision of social self-determination and cultural diversity; and (e) maintenance of ecological integrity (Lele, 1991). The Brunndt Report (1987) referred to SD which meets the needs of the present without compromising the ability of future generations to meet their own needs. SD is a belief that human development cannot happen without healthy planet. The 2002 World Summit on SD in Johannesburg pledged to strengthen the mutually reinforcing pillars of local, national, regional, and global levels with the goal to banish underdevelopment forever. The 2012 UN Conference on SD in Rio de Janerio (Rio+20) endorsed the 2002 agreement and emphasized good governance and integrated planning in achieving SD. After Rio+20 an inclusive intergovernmental process began to formulate the SD goals. Achieving high standards of human welfare and ensuring the long term viability of the natural world are both cornerstone goals of sustainable development.

Many development assistance agencies now aspire to the dual mission of alleviating poverty and conserving environment. Conservation organizations are claiming that their activities are yielding benefits for the poor. They maintain that natural resources can be managed in ways that achieve immediate benefits for local people whilst sustaining long-term local and global environmental values. However, many critics maintain that the lack of success of both development and conservation programs in developing counties results from the confusion of these two inherently divergent agendas. 
The 2016 Global Education Monitoring Report has established that education is at the heart of sustainable development. Education plays a major role in the transformation towards more environmentally sustainable societies and in addressing the impact of environmental crises such as climate change. Over population (mainly in the developing countries) and unsustainable lifestyles (mainly in the developed countries) are the main factors leading to over-use of the limited resources on the planet Earth. The 2030 Agenda unites global development goals in one framework. Education with SD is founded on the principles drawn from a rich history of international instruments and agreements. Increased educational attainment helps transform lives by reducing poverty, improving health outcomes, advancing technology and increasing social cohesion. It can also enable individuals to better cope with, and reduce their vulnerability to the dangers associated with climate change. Education is associated with increased environmental awareness, concerns and action. Across the 57 countries participating in the 2006 Program for International Students Assessment (PISA) of the OECD, students who scored higher in environmental science reported higher awareness of complex environmental issues. Education encourages individuals to protect environment and use water and energy more efficiently and recycle household waste. The 2010-12 World Values Survey showed that if they were to choose between protecting the environment versus boosting economy those respondents with secondary education favored the environment more than those with less than secondary education. The notion of lifelong education is especially apt. It is essential to have a sustainable development agenda, supported by political leadership, in which education for global citizenship and sustainable future is explicitly prioritized. Embarking upon the ultimate purpose of learning throughout life education has the power like none else to nurture empower, be reflective, engaged and skilled citizens who can chart the way towards a safer, greener and firer planet for all (Irina Bokova-Director General UNESCO 2016).

A sustainable future for all is about human dignity, social inclusion and environmental protection. It is a future which brings prosperity for all, where urban areas and labor markets are designed to empower everyone economically as well as makes them green-oriented.

\section{WHAT IS ENVIRONMENTAL EDUCATION (EE)?}

Environmental Education is relatively young and immensely complex field to study and interpret. First international conference on EE was held in Tbilisi in 1977. At this conference guidelines for developing $\mathrm{EE}$ were laid. As an educational approach $E E$ can permeate a range of disciplines, both traditional and new, as well as form the mainspring of many integrated courses (Palmer, 1998, p.9). In this era the natu- 
ral world is under threat. Different species of flora and fauna are on the verge of extinction; air, water and food are polluted and contaminated. In the 1990s it shifted its focus on sustainability. It contributes to the education of 'whole person'. Environmental education is a process that allows individuals to explore environmental issues, engage in problem solving, and take action to improve the environment. It is hands-on, interdisciplinary, empowering and relevant to learners' everyday life. It gives them the knowledge and tools they need to be environmentally literate-ready to face environmental and social challenges with confidence and optimism (The Economist, 2016). The US Environmental Protection Agency (2006) defines the components of EE as follows:

- Awareness and sensitivity to the environment and environmental challenges;

- Knowledge and understanding of the environment and environmental challenges;

- Attitudes of concern for the environment and motivation to improve or maintain environmental quality;

- Skills to identify and help resolve environmental challenges;

- Participation in activities that lead to the reduction of environmental challenges.

The process of EE is as follows:

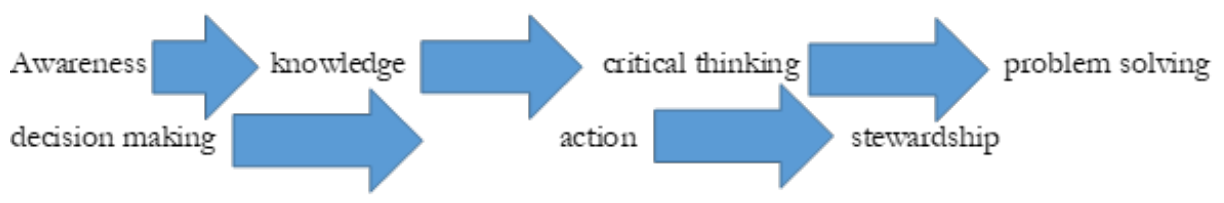

Environmental education is a process that allows individuals and groups to explore environmental issues, engage in problem solving and take action to improve the environment. Individual gain awareness of their environment and acquire knowledge. They develop critical thinking to tackle problems. People develop leadership skills and take decision and responsible action to improve the environment.

As hands-on and interactive process EE offers opportunities for experiential learning outside of the classroom, enables students to make connections and apply their learning in the real world. EE promotes a sense of place and connection through community involvement. It helps students understand how their decisions and actions affect the environment, builds knowledge and skills necessary to address complex environmental issues. By incorporating EE practices in to the curriculum teachers can integrate other subjects into one rich lesson or activity. Students learn to make connections and apply their learning in the real world.

$\mathrm{EE}$ for sustainability is based on the premise of integration. It makes us 
aware of our responsibilities to the future generations. EE for sustainability is viewed as a vehicle for sustainable development. It provides important opportunities for students to become engaged in real world issues. Students can see the relevance of their classroom learning to the complex environmental issues confronting our planet and they can acquire the skills which they will need to be creative problem solvers and powerful advocates. Meeting the needs of our global citizenry -ecologically, economically, and culturally- requires understanding and creative problem solving.

Environmental problems are not solely caused by physical and biological factors, but by an understanding of many elements such as social, economic, cultural, historical and ethical elements. It acknowledges that the investigation of any environmental issue must involve the study of interaction of these elements. EE for sustainability adopts a holistic outlook to the study of environmental problems, reflected in its interdisciplinary approaches. The interdisciplinary teacher cooperation is a model of EE for sustainability.

A holistic EE cannot be claimed as a subject in itself, rather it must be treated as 'whole' concept that requires inputs from all parts of the curriculum. Environmental Education deals with questions such as: how over-consumption, waste and misuse of resources are reduced; how poverty that sometimes causes environmental exploitation can be eliminated; how economic activities may be altered to minimize environmental deterioration; which forms of social organizations best contribute to sustainable development (Beddis and Jackson, 1998). Environmental education should simultaneously attempt to create awareness, transmit information, develop habits and skills, promote values, provide criteria and standards and present guidelines for problem-solving and decision-making about environmental issues. It therefore, aims at both cognitive and affective behavior modification. The latter necessitates both classroom and field activities. This is an action-oriented, project-centered and participatory process leading to self-confidence, positive attitudes and personal commitment to environmental protection. Furthermore, the process should be implemented through inter-disciplinary approach (UNESCO-UNEP, 1987). Environmental education equips learners with knowledge skills and motivation to address complex environmental challenges in the 21 st century. Unfortunately, even though the approach is growing in popularity, it still remains the exception rather than the rule (Hargreaves, 2016). EE is still in its infancy.

\section{ENVIRONMENTAL EDUCATION AND TEACHER TRAINING}

In 1997, UNESCO Report Education for a sustainable Future stated "Education is humanity's best hope and most effective means in the quest to achieve sustainable development. "The only way to achieve this is to elaborate, develop, practice and argue for a changed 
educational program. The current EE problems lie not only with what has been taught but also with the way EE curricula are developed, evaluated" (Blumestein and Saylan, 2007). Focus of $\mathrm{EE}$ is to develop environmental literacy. It strives to increase public awareness and knowledge of the environment and provide skills necessary to make informed environmental decisions and to take responsible actions. Teacher training is an essential element to introduce environmental education in schools. It provides a context for learning in which the learner can develop a deeper connection to nature and develop the problem-solving skills to address various environmental issues. EE cannot be successfully carried out without introducing it in teacher training for pre-service teachers. A leading educationist Michael Fullan aptly sums up the vital role teachers can play in EE. "Any educational change depends on what teachers do and think. It is important to have a team of well-trained teachers and educators to guarantee the success of educational change" (Fullan, 2007). The thrust of Nature Schools, launched in Finland in 2016 is to develop teacher education program where $\mathrm{EE}$ is given a major priority. The logic is if teachers themselves do not have the awareness of EE how can they welcome the integration of EE into school curriculum and how can they guarantee a successful EE? This author asserts that a meaningful acceptance of EE certainly depends upon how well teachers are trained, how much encourage- ment comes from school leadership and how well $E E$ is integrated in school curricula. A comprehensive networking effort, including a wide range of players, organizations and community members can make EE a successful educational change.

\section{Vi. Approaches to Teach ENVIRONMENTAL EDUCATION}

In many developed countries and lately in some developing countries of south and Southeast Asia Concerted efforts are being initiated to make EE as part of the curriculum particularly at school level. Most common approaches are briefly discussed here.

\section{WHOLE-SCHOOL APPROACH: FROM PILOT PROJECT TO SYSTEMATIC CHANGE}

Even though there is support for ESD at national and international levels there are a few concrete examples of schools in which this approach has been systematically implemented. A more common trend appears to be partial implementation of just a few aspects of ESD as curriculum add-ons. However, these approaches fall short of achieving the objective of a whole school approach to ESD. Holistic view of ESD implies more of inter-disciplinary approach and better linkages among the different school subjects as well as a growing need for more thematic teaching. At the same time, in order to be able to work with holistic and thematic approaches, the learners need a lot of 
specified and detailed knowledge provided by traditional subject studies. The challenge is to combine these supposed contradictions and find ways to let our teaching within traditional subjects be influenced by holistic and trans-disciplinary perspectives. Where examples of the whole-school approach do exist, they tend to be pilot projects in individual schools rather than a system-wide or school-based approach to implementation. Education for Sustainable Development demands an inter-disciplinary approach and better linkages of the different school subjects as well as growing need for more thematic teaching. By combining a deeper and more integrated understanding with social and collaborative learning, students will explore making sustainable choices about their own lives and lives of others and their common environment. This profound shift of the goals of our education systems is a world-wide process with a large number of actors arguing for ESD. The aim of ESD is 'to integrate the principles, values and practices of sustainable development in all aspects of education. This educational effort will encourage changes in behavior that will create a more sustainable future in terms of environmental integrity, economic viability and a just society for present and future generations. As such ESD seeks to prepare people to cope with and find solutions to problems that threaten the sustainability of the planet" (UN Decade of education for SD 2005-2014). UNESCO has emphasized that ESD should be locally relevant.

\section{WHOLE-SCHOOL APPROACH TO \\ EDUCATION FOR SUSTAINABLE \\ DEVELOPMENT}

A whole school approach to ESD is integrated throughout the formal sector of curriculum in a holistic manner rather than taught on a standalone basis. This philosophy supports the notion that ESD is education for SD rather than education about SD. Australia's National Statement for the UN Decade of ESD, for example, cross-disciplinary studies and integration of SD in key learning areas provide opportunities for participation and action (Australian Department of Environment and Heritage, 2006).

The United Kingdom echoes this approach and has advocated for the integration of SD throughout the curriculum and through the management and operations of school facilities, such as transport, food and building (UK Department of Education and Skills, 2005). These approaches provide students, teachers and other staff members with opportunities to be active participants in the learning process.

\section{INTEGRATED APPROACH TO EE/ MULTIDISCIPLINARY APPROACH}

Schools and universities are called upon to act as role models for sustainable development. The whole-school approach to environmental education consists of curriculum, extracurricular activities, teacher-training (McMillan and Dyball, 2009) and it addresses the needs of learners, staff and the wider community to make a joint effort. It includes collective and collaborative ac- 
tion in and by a school community to improve student learning about global environmental issues (UNESCO, 2013). This approach encourages institutions to change buildings, grounds and school schedules accordingly and to engage with the local community (Anderson, 2012). It improves schools ethos and student learning and health.

Sustainable development meets the needs of the present without compromising the ability of future generations to meet their own needs (World Commission on Environment and Development (1987). It has three dimensions: ecological, social and economic. The im- plications of making development socially and ecologically sustainable differs for developed and developing countries. Developed countries have large capital stock and extensive infrastructure and many other elements essential to modern economic production. Developing countries have a different set of problems in achieving sustainability. Because thy start from much lower income levels, their major social and economic goal is to increase production. The combination of increased population and economic growth creates strong pressure for rising resource use and increased generation of waste and pollution.

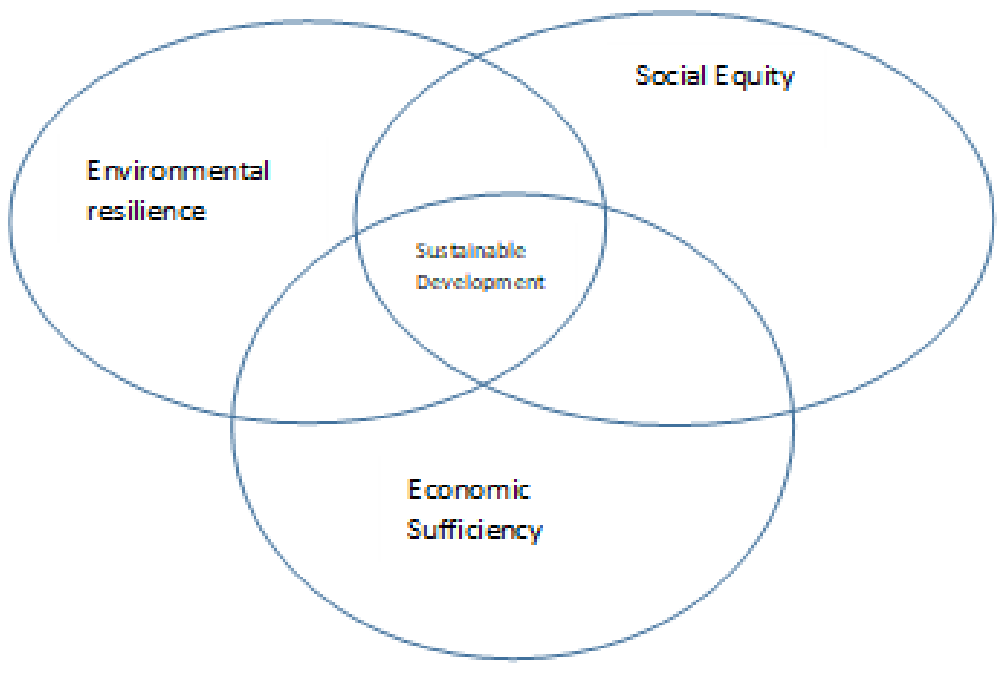

Educating the people about the perils of environmental degradation is a major responsibility of schools. The most effective approach schools could adopt is the 'holistic-thematic approach to the issues such as waste disposal, contamination of rivers, threat to flora and fauna due to commercial farming.
A CASE STUDY OF A SUCCESSFUL PILOT PROJECT: AUSSI (AUSTRALIAN SUSTAINABLE SCHOOLS INITIATIVE)

AUSSI is a partnership between Australian government, States and Territories that aims to support schools and their communities in becoming sustainable through a whole-system and 
whole-school approach to sustainability. It promotes the active engagement of stakeholders in program development and management including students, teachers, administrators and communities. AUSSI started in 2001 and recently it has been endorsed by the government to expand and consolidate beyond pilot stage. Over 2000 schools participate in this project providing a potential model for other jurisdictions on how to expand beyond the pilot stage (Hargreaves, 2016).

The International Eco-Schools Program also takes a holistic participatory approach to learning for sustainability. The aim of the program is to engage students through classroom study, school and community action to raise their awareness of sustainable development issues. Eco-Schools provide an integrated system for the environmental management of schools and involves all stakeholders in this process. After a period each school participating in the program is assessed. Successful schools are awarded a 'Green-Flag', a recognized eco-label for performance in EE. Eco-Schools are now represented in almost all European Union member States, various countries in Central and Eastern Europe and some pilot projects in Japan and other parts of the world. Funded by the US National Foundation, Pacific Islands aim to educate the region's students and citizens ways that exemplify modern science and indigenous environmental knowledge address the urgency of climate change and hon- or indigenous culture. Students will have the knowledge and skills to advance their understanding of climate change and adapt to its impact.

\section{Thematic Approach: FINNISH MOdEL}

Finland maintains that the teaching of sustainable development must be included in all subjects and the entire operational culture of a school must support learning for SD (Finland National Commission on SD, 2006). Finland provides an example of a country in which whole-school approach is more systematically implemented in the formal education system than in most other OECD nations. Seven cross-cutting themes penetrate all formal subjects in the Finnish school curriculum at primary and secondary schools. These themes include development education, cultural identity, internationalism, responsibility for nature and SD (Finnish National Commission on SD 2006). These themes help define the operational culture of schools and include cultural identity, participatory citizenship, responsibilities for the environment, SD and media skills (Houtsonen, 2005).

Thematic approach is extremely effective for integrating curriculum and for teaching skills in context. It refers to any approach that integrates learning across curriculum with some organizing connection that gives a sense of unity to the study (Geoff Ward- http://researchonline.jcu.edu.au/529/ward_1.pdf). This is a way of teaching and learning, 
whereby many areas of curriculum are connected together and integrated within a theme. It allows learning to be more natural and less fragmented where a school day time is divided into different subject areas. It guides connected ideas to follow easily, encourages active student involvement, develops learning skills more quickly, provides students with exposure to a broad theme, and motivates students to investigate the problem from different angles.

The most recent approach to teaching in primary and high school in Finland is phenomenon-based thematic teaching. Curriculum focuses on developing skills that transverse multiple subjects, Competencies include ICT, cross-cultural communication, active participation in society and entrepreneurship. Students learn at least one phenomenon-based inter-disciplinary module per year. These modules require them to learn and apply variety of skills and competencies within a single lesson unit instead of studying subjects such as mathematics and geography, separately. Phenomenon-based learning allows students to take charge of their learning. The key is for teachers to provoke students to ask questions. Students get individual feedback. Schools and school leaders strive to build a cooperative rather than competitive learning among students.

For example, inter-disciplinary module could be 'effects of climate change' or effects of eco-tourism on biodiversity'. On this theme students develop a global awareness campaign on You Tube to persuade their peers nationally and inter-nationally to conserve the environment.

Curriculum on EE with a thematic approach harnesses environment's aesthetic and inspiring qualities in order to arouse students' curiosity and encourage them to become more aware of the aspects of natural environment. Holistic thematic approach awakens environmental knowledge through creative and thought stimulating activities that encourage rediscovery and appreciation of the natural environment and biodiversity.

Thematic approach to EE offers opportunities for students to learn through more contextualized learning experiences, exposes them to linkages between school-based learning and learning that occurs in work place, community and natural environment and human imprints on the environment. Teacher work together as members of self-directed professional teams with powerful learning strategies. Taught by a team of teachers students do group activities on real-life problem solving. Professional Development School in teaching practice was effective for developing some aspects of the students' personal traits and teaching skills (Ali, M., 2003) This integrated, inter-disciplinary approach leads to deeper understanding of the issue when student work in groups and find/offer solution. Teachers as facilitators steer students to (say) understand conservation and sustainable development. Learning for sustainability through thematic approach is 
not solely about integrating new content into the curriculum, it is about challenging teaching and learning approaches. Schools, educators and policy makers need to understand the best practice in learning for sustainability. Thematic integrated to $\mathrm{EE}$ is concerned with the ability of students to participate, influence, share and/or control the learning process. It allows students to participate on the basis of equity, sharing, listening, reflection, negotiation, critical thinking, collaboration, trust and influence-orientation. Students' background factor included gender, age, grade repetition, resources at home, parent's education and expected level of educational attainment, are correlated with student's achievements (Ali, M \& Hayat, B., 2019.) Building these core capacities (21st century skills) is a core objective of learning for sustainability. Leaning for sustainability equips, involves both students and institutions in reflecting on how they currently live and work.

\section{Conclusions}

It is widely accepted that modern global environmental challenges are characterized by uncertainty, irreversibility and uniqueness and non-sustainability (Pearce, 1990). Loss of biodiversity, declining health of aquatic resources and human-induced climatic change are big issues. As a global society, we should ensure that the international rules of the game in economic management do not set snares along the lower rungs of the ladder in the form of inadequate development assistance, protectionist trade barriers (e.g. Trump's election slogan and subsequent action: We shall make America Great again) that prevent the low income world from climbing up the rungs of development (Sachs, 2005, p. 25). Right now preparing students to be good environmental citizens is the responsibility of teachers, schools and administrators. The pace at which the world population is galloping and demand for resources is increasing, education for sustainable development must become priority in our educational institutions. The way we plan today for public education on the environment will have dramatic effects on the future quality of life. Effective and meaningful education is a challenge we must take seriously if we and the future generations are to enjoy the benefits of our natural heritage. One major problem is that environmental problems fall prey to the political agendas of those who have a vested interest in an unsustainable, resource-extractive approach to economic development. When global companies undertake to clear the natural vegetation for commercial gains it is the responsibility of the host nation to realize the long term detrimental effects on the ecology of the area. Resource-extractive approach to economic development is unsustainable. Environmental education must teach about science itself and about the use of the scientific method to help evaluate and respond to environmental threats.

Macro-economic changes and increased climate variability will be the major determinants of the condition of human life for many poor countries. 
A number of 'external' environmental, economic and social problems are now threatening the long-term performance of the agricultural, forestry, livestock and fishery systems upon which poor people depend. Science and technology (of the richer nations) must contribute understanding of how these phenomena will impact on ordinary people. Concepts and tools now exist for a science-based approach to the integrated management of natural resource systems. "If the real needs of the rural poor in developing countries are to be met, then science must deal with the natural resource system upon which they depend for their livelihood... Effective research should link seamlessly with the knowledge of these clients" (Sayer and Campbell, 2005, p. 27). Inaugurating The Clean India Movement India's Prime Minister's challenge to clean the environment applies to all. "India faces challenges but that does not mean we run away from them. The dream will be realized by 1.3 billion Indians" (Narendar Modi, 2 October, 2018). In fact, environmental challenges are for the entire humanity. A collective vision and action is required for sustainable development and to realize the wellbeing of the future generations.

\section{REFERENCE}

Ali, M. (2003) The Use of Professional Development School for Developing Student-Teachers' Professional Competencies. In IASTED Internatonal Conference on Computers and Advanced Tech- nology in Educational Symposium on Web-Based Education (pp. 765-770).

Ali, M. \& Hayat, B. (2019). Non-academic Factors Influencing students' Achievement: A Study in The Indonesian Madrasahs. International Journal of Learning and Intelectual Capital, 16 (2), 180-192.

Australian Association for Environmental Education Biennial (2018). https://aaee2018.com.au/

Beddisish, R. and Johnson, C. (1998). Only one Earth: a multimedia education pack.

Blumstein, D. and Saylan, C. (2007). The Failure of EE and how we can fix it. Plos Biology 15 (5).

Fullan, M. (2007). (2007). The new meaning of educational change. 4th ed. New York: Teachers College Press.

Indonesia vows to tackle marine pollution (March 9, 2017). AEDT.

Jean-Jackues, D. (April, 2017). Trash, Cities and Politics: Urban Environmental Problems in Indonesia. Southeast Asia Program Publications at Cornell University.

Mauree, Jin (2014). The Importance of out-of-school environmental education entities for integrating EE into school curriculum. Master Thesis.

Pearce, D. (1990). Economics and Global Environmental Challenges. Millenium, 19(3), pp.365-87.

Pingle, A. et al. (March 2, 2017). Global Environmental Change in Indonesia: Around table. 
Edgeeffects.net/environmental-change-Indonesia/

Sahlberg, P. (2011). Finnish lessons: What can the world learn from educational change in Finland? New York. Teachers College Press.

Sayer, J. and Campbell, B. (2005). The Science of Sustainable Development. Cambridge University Press.

Sterling, S. (2001). Sustainable education. UK Green Books Ltd.

Stohr, W. (2013). Coloring a green generation: The Law and Policy of Nationally-mandated environmental education and social value formulation of the primary and secondary academic levels. Journal of Law and Education. 42 (1). pp. 1-110.

UNO Declaration (2017). Education for Sustainable Development. www.heacademy.ac.uk. Retrieved 3.10.2018.

UNESCO (2005). http://unes codoc.unes co.org/images/001486/1486540.pdf.

UNECO-UNEP (1987). unesdoc.unesco.org/images/00805/08058300. pdf

UNESCO (1980). Environmental Education in the light of the Tbilsi Conference. Paris: UNESCO 